\title{
Evaluasi Keberlanjutan Terminal Berbasis Transit Oriented Development (TOD), Studi Kasus di Terminal Pal Enam Kota Banjarmasin
}

\section{Sustainability Evaluation of Terminal Based on Transit Oriented Development (TOD), Case Study atTerminal Pal Enam Banjarmasin City}

\author{
Miftahul Ridhoni ${ }^{1 *}$, Muhammad Yusuf Ridhani ${ }^{2}$ \\ 1,2 Program Studi Perencanaan Wilayah dan Kota, \\ Fakultas Teknik, Universitas Muhammadiyah Banjarmasin
}

\begin{abstract}
Abstrak
Saat ini fokus pembangunan pemerintah nasional dan daerah di berbagai negara adalah meningkatkan kualitas transportasi publik untuk menanggulangi permasalahan yang diakibatkan oleh kesemrawutan lalu lintas keadaan pribadi pada wilayah perkotaan. Konsep Transit Oriented Development (TOD) hadir sebagai alternatif dalam penanganan permasalahan transportasi perkotaan dengan mengintegrasikan kebijakan infrastruktur transportasi, guna lahan dan lingkungan. Dengan disahkannya Permen ATR BPN RI Nomor 16 Tahun 2017 tentang Pedoman Pengembangan Kawasan Berorientasi Transit maka perlu dilakukan penilaian terhadap kesiapan area dan sarana transit perkotaan untuk mengetahui apakah tema tersebut dapat diimplementasikan. Penelitian ini bertujuan untuk melakukan penilaian terhadap aplikasi konsep TOD di Kawasan Terminal Pal Enam Kota Banjarmasin dengan menggunakan 8 variabel kerja yaitu Walk, Cycle, Connect, Transit, Mix, Densify, Compact, dan Shift. Hasil penilaian menunjukan Kawasan Terminal Pal Enam Kota Banjarmasin sudah memenuhi standar TOD dengan kategori Bronze. Lokasi Terminal Pal Enam Kota Banjarmasin bukan hanya berperan sebagai Kawasan Strategis Ekonomi untuk mewadahi kebutuhan transit dan keterpaduan antar moda namun juga memenuhi ekspektasi sebagai salah satu pioner penerapan konsep TOD.
\end{abstract}

Kata kunci: Area Terminal, Penilaian, TOD

Abstract

At the moment there are various urban problems caused by the traffic in urban areas of various countries. Therefore, the main focus of national and regional development in those countries is to improve the quality of public transportation. Transit Oriented Development (TOD) is an alternative approach to solve the urban transportation problem by integrating transportation, land use, and environment policies. The enactment of ATR BPN RI Number 16/2017 on Transit Oriented Area Development Guidance opens the opportunity to evaluate urban transit areas and facilities to find out whether the concept can be implemented. This study was conducted to evaluate application of TOD's concept in Terminal Pal Enam Area of Banjarmasin City by using 8 work variables, namely Walk, Cycle, Connect, Transit, Mix, Densify, Compact, and Shift. The results of the evaluation indicated that the Terminal Pal Enam Kota Banjarmasin area has met the TOD's standard in Bronze category. Terminal Pal Enam Kota Banjarmasin is not only an Economic Strategic Area which accommodate the needs of transit and integration between modes, but it also meet the expectation of being the TOD's concept pioneer.

Keywords: Assessment, Station Area, TOD

\section{PENDAHULUAN}

Setelah pembangunan wilayah perkotaan berjalan dalam kurun waktu beberapa dekade, saat ini pemerintah nasional dan daerah di berbagai negara mengalihkan fokus pembangunan dalam rangka meningkatkan kualitas transportasi publik. Peningkatan kualitas transportasi publik bertujuan untuk

Alamat Korespondensi Penulis: Miftahul Ridhoni

Email : ridhonimiftahul@gmail.com

Alamat : Jl Gubernur Syarkawi, Kode Pos: 70582 menanggulangi permasalahan ekonomi, sosial, dan lingkungan yang diakibatkan oleh kesemrawutan keadaan lalu lintas kendaraan pribadi pada wilayah perkotaan [1].

Dinamika perkotaan terefleksikan dalam bentuk hubungan interaksi antara manusia dan lingkungan dalam konteks spasial pada waktu tertentu. Dalam kompleksitas sistem tersebut, strategi spasial tertentu seperti kebijakan infrastruktur transportasi yang bersifat parsial tidak dapat diandalkan dalam mencapai keberlanjutan. Sehingga diperlukan strategi yang 
terintegrasi antara kebijakan infrastruktur transportasi, guna lahan, serta lingkungan [2]. Konsep Transit Oriented Development (TOD) adalah pengaturan secara spasial melalui pengalokasian pusat-pusat aktivitas disekitar area transit atau infrastruktur transit seperti terminal atau stasiun. Kemudian pembangunan disekitarnya didasarkan pada karakteristik kompak, penggunaan campuran, serta lingkungan yang bersahabat bagi pejalan kaki dalam area yang terjangkau untuk berjalan dari dan menuju area transit atau fasilitas transit [2].

Penerapan konsep TOD memiliki beberapa keuntungan yaitu mengurangi polusi udara, mengurangi biaya perjalanan transportasi dan menghemat waktu perjalanan serta mengurangi kongesti di wilayah perkotaan akibat berkurangnya penggunaan transportasi pribadi [3].

Dalam perkembangan perkotaan, kawasan transit seperti terminal dan pelabuhan dan fasilitas transit intermoda telah menjadi aspek yang tidak terpisahkan. Daerah disekitar titik transit merupakan kawasan potensial untuk dikembangkan. Hal ini terkait dengan kemudahan akses yang ditawarkan kawasan lokasinya berdekatan fasilitas transit dengan mempertimbangkan bangkitan yang ditimbulkan oleh fasilitas tersebut [4].

Konsep TOD dapat diterapkan di kawasan yang dianggap sudah mengalami penurunan baik fungsi dan kualitas fisiknya dan harus mengalami proses redevelopment (pembangunan kembali) maupun di kawasan infill site (lahan yang sudah berkembang) dan new growth site (lahan pengembangan baru). Konsep TOD ini biasanya memberikan atau menciptakan fungsi-fungsi baru dan memperbaiki jaringan sistem transit yang berada dalam kawasan ataupun menciptakan jaringan sistem transit yang baru [5].

Terdapat perbedaan antara perencanaan dan konstruksi sistem TOD dalam konteks wilayah yakni pada pusat kota dan area pinggiran. TOD pada pusat kota cenderung memiliki fasilitas yang lengkap, tersedia untuk tujuan perjalanan yang lebih beragam, serta dibuat untuk mengakomodir potensi perjalanan skala besar. Padahal jika berbicara perspektif yang lebih luas, po tensi bangkitan transportasi yang lebih besar adalah dari daerah pinggiran menuju pusat kota. Selain itu, perencanaan dan konstruksi sistem TOD sebagai bagian dari perluasan sistem transit bagi masyarakat memberikan kesempatan pada area disekitar fasilitas transit untuk berkembang dan terevitalisasi [6].

UU No. 22 Tahun 2009 tentang lalu lintas dan angkutan jalan menjelaskan bahwa terminal merupakan pangkalan kendaraan bermotor umum yang digunakan untuk mengatur kedatangan dan keberangkatan, menaikkan dan menurunkan orang atau barang serta perpindahan moda angkutan. Kemudian menurut jenisnya terminal dapat dibagi atas terminal tipe $A$, tipe $B$, dan tipe $C$ [7].

Dalam konsep wilayah, terdapat perbedaan antara perencanaan dan konstruksi sistem TOD pada pusat kota dan area pinggiran. TOD pada pusat kota cenderung memiliki fasilitas yang lengkap, tersedia untuk tujuan perjalanan yang lebih beragam, serta dibuat untuk mengakomodir potensi perjalanan skala besar. Padahal jika berbicara perspektif yang lebih luas, potensi bangkitan transportasi yang lebih besar adalah dari daerah pinggiran menuju pusat kota. Selain itu, perencanaan dan konstruksi sistem TOD sebagai bagian dari perluasan sistem transit bagi masyarakat memberikan kesempatan pada area disekitar fasilitas transit untuk berkembang dan terevitalisasi[3].

Terminal Pal Enam Kota Banjarmasin merupakan terminal induk tipe $B$ yang diselenggarakan untuk angkutan bus dan taksi antar kota oleh Pemerintah Provinsi Kalimantan Selatan berdasarkan Perda Provinsi Kalimantan Selatan No. 9 Tahun 2015 tentang Rencana Tata Ruang Wilayah Provinsi Kalimantan Selatan Tahun 2015 - 2035. Terminal Pal Enam Kota Banjarmasin yang dikelola sebagai Unit Pelaksana Teknis Daerah (UPTD) memiliki lokasi strategis sebagai simpul angkutan darat pintu gerbang dari dan menuju Kabupaten, Kota lain di Provinsi Kalimantan Selatan (Gambar 1). Berdasarkan Perda Kota Banjarmasin No. 5 Tahun 2013 tentang Rencana Tata Ruang Wilayah (RTRW) Kota Banjarmasin Tahun 2013-2032, Terminal Pal Enam Kota Banjarmasin diarahkan untuk dikembangkan sebagai kawasan strategis ekonomi dengan menganut sistem keterpaduan antar moda. Kebijakan tersebut sejalan dengan pengembangan sistem TOD dimana simpul transportasi menjadi sentra transit bagi beragam aktivitas.

Dalam hal pembangunan sarana prasarana pendukung terminal, pemerintah daerah diarahkan untuk mengacu pada 
Permenhub RI No. 132 Tahun 2015 tentang Penyelenggaraan Terminal Penumpang Angkutan Jalan

Pilihan dalam tema pengembangan pembangunan perkotaan secara formal menjadi lebih beragam sejak disahkannya Permen ATR BPN RI Nomor 16 Tahun 2017 tentang Pedoman Pengembangan Kawasan Berorientasi Transit. Penilaian terhadap kesiapan area dan sarana transit perkotaan perlu dilaksanakan untuk mengetahui apakah tema tersebut dapat diimplementasikan. Salah satu mekanisme penilaian yang dapat digunakan yaitu standar penilaian oleh ITDP.

\section{METODE PENELITIAN}

Penelitian menggunakan metode observasi dengan penekanan pada penggunaan data kualitatif. Teknik analisis yang digunakan adalah multi criteria evaluation (MCE) yang dapat menganalisis informasi yang jumlahnya banyak secara terstruktur dengan menggunakan The TOD Standard dari Institute for Transportation \& Development Policy (ITDP) sebagai alat penilaian, penelaahan, dan petunjuk, berfokus pada pengintegrasian transportasi yang berkelanjutan dengan perencanaan serta perancangan guna lahan [1] [9].

\section{Variabel}

8 variabel dalam The TOD Standard oleh ITDP terdiri atas walk, cycle, connect, transit, mix, densify, compact, dan shift. Variabel, pengertian serta indikator penilaian dapat dilihat pada Tabel

1. Pada penelitian, terdapat pembatasan penggunaan indikator. Hal ini berkaitan denganbeberapa pertimbangan, yaitu:
1) Walaupun disusun secara komprehensif untuk tujuan pembangunan berkelanjutan secara ideal, namun standar mengacu pada kota-kota di Benua Eropa. Perlu penyesuaian antara indikator dengan kondisi di Indonesia khususnya Kota Banjarmasin.

2) Secara eksisting, tidak semua indikator ada pada kota-kota di Indonesia khususnya Kota Banjarmasin;

Pembatasan indikator The TOD Standard

Kemudian kriteria ITDP yang digunakan dan tidak digunakan pada penelitian dapat dilihat pada Tabel 2.

Berdasarkan Permen ATR BPN RI Nomor 16 Tahun 2017 tentang Pedoman Pengembangan Kawasan Berorientasi Transit, kriteria lokasi yaitu:

1) berada pada Simpul Transit jaringan angkutan umum massal yang berkapasitas tinggi berbasis rel;

2) memenuhi persyaratan intermoda dan antarmoda transit;

3) dilayani paling kurang 1 (satu) moda transit jarak dekat dan 1 (satu) moda transit jarak jauh;

4) sesuai dengan arah pengembangan pusat pelayanan dan kegiatan;

Berdasarkan penelaahan kebijakan dan kondisi eksisting, Terminal Pal Enam telah memenuhi persyaratan sebagai lokasi pengembangan konsep TOD.
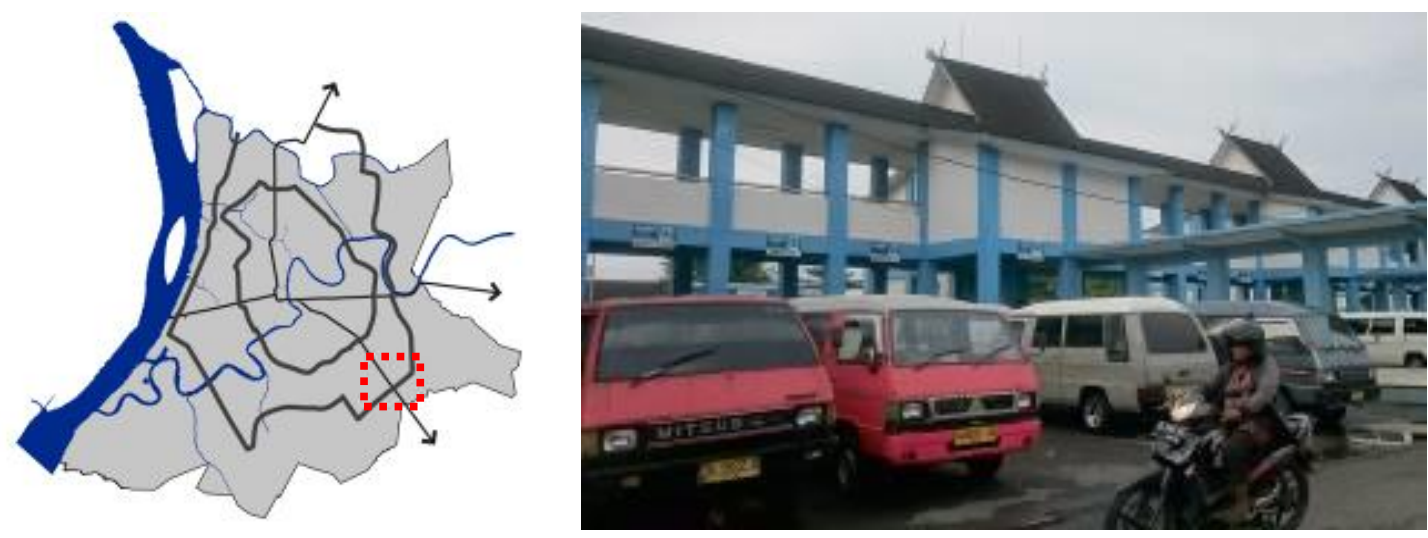

Gambar 1. Terminal Pal Enam Kota Banjarmasin Sumber: City Visioning Profile, 2012[4] 
Tabel 1. Variabel The TOD Standard (ITDP)

\begin{tabular}{|c|c|c|}
\hline Variabel & Sub Variabel & Indikator \\
\hline Walk & $\begin{array}{l}\text { Ranah pejalan } \\
\text { kaki tersedia } \\
\text { lengkap dan } \\
\text { aman } \\
\text {. Ranah pejalan } \\
\text { kaki aktif dan } \\
\text { bergairah } \\
\text {. Ranah pejalan } \\
\text { kaki aman dan } \\
\text { nyaman }\end{array}$ & $\begin{array}{l}\text { - Walkways/Pedestrian way ( } 3 \text { points) }: 0=\text { sama sekali tidak tersedia, } 1=\text { tersedia }<=30 \\
\text { persen, } 2=\text { tersedia }<=60 \text { persen, } 3=\text { tersedia } 100 \text { persen } \\
\text { - Crosswalk/Zebra cross ( } 3 \text { points) }: 0=\text { sama sekali tidak tersedia, } 1=\text { tersedia }<=30 \\
\text { persen, } 2=\text { tersedia }<=60 \text { persen, } 3=\text { tersedia } 100 \text { persen } \\
\text { - Visually Active Frontage/fasad bangunan disekitar terminal dapat diakses secara visual } \\
\text { ( } 6 \text { points) }: 0=\text { sama sekali tidak dapat diakses secara visual, } 2=\text { dapat diakses secara } \\
\text { visual }<=30 \text { persen, } 4=\text { dapat diakses secara visual }<=60 \text { persen, } 6=\text { dapat diakses } \\
\text { secara visual } 100 \text { persen } \\
\text { - Physically Permeable Frontage/bangunan disekitar terminal dapat diakses secara fisik } \\
\text { ( } 2 \text { points) }: 0=\text { sama sekali tidak dapat diakses secara fisik, } 1=\text { dapat diakses }<=50 \\
\text { persen, } 2=\text { dapat diakses } 100 \text { persen } \\
\text { - Shade } \& \text { Shelter } / \text { ketersediaan teduhan alami maupun buatan disekitar terminal }(1 \\
\text { points) }: 0=\text { sama sekali tidak sedia teduhan, } 1=\text { tersedia teduhan }\end{array}$ \\
\hline Cycle & $\begin{array}{l}\text { Jaringan jalur } \\
\text { sepeda tersedia } \\
\text { lengkap dan } \\
\text { aman } \\
\text { Parkir sepeda } \\
\text { yang cukup dan } \\
\text { aman }\end{array}$ & $\begin{array}{l}\text { - Cycle Network/ketersediaan jalur sepeda ( } 2 \text { points) : } 0=\text { sama sekali tidak sedia jalur } \\
\text { sepeda, } 1=\text { tersedia jalur sepeda } \\
\text { - Cycle Parking at Transit Stations/ketersediaan parkir sepeda di terminal ( } 1 \text { points) }: 0= \\
\text { sama sekali tidak sedia parkir sepeda, } 1=\text { tersedia parkir sepeda } \\
\text { - Cycle Parking at Buildings/ketersediaan parkir sepeda di bangunan sekitar terminal ( } 1 \\
\text { points)::0 = sama sekali tidak sedia parkir sepeda, } 1=\text { tersedia parkir sepeda } \\
\text { - Cycle Access in Buildings/aturan mengenai akses sepeda kedalam bangunan ( } 1 \\
\text { points) : } 0=\text { tidak tersedia peraturan yang mengatur akses sepeda pada frontage } \\
\text { bangunan, } 1=\text { tersedia aturan }\end{array}$ \\
\hline Connect & $\begin{array}{l}\text { Rute berjalan } \\
\text { dan bersepeda } \\
\text { pendek, } \\
\text { langsung, dan } \\
\text { bervariasi }\end{array}$ & $\begin{array}{l}\text { Small Block/ukuran rata-rata diagonal blok disekitar terminal ( } 10 \text { points) }: 0=\text { ukuran } \\
\text { rata-rata diagonal blok disekitar terminal }>=500 \mathrm{~m}, 2=\text { ukuran diagonal blok }>=400 \mathrm{~m}, 4 \\
=\text { ukuran diagonal blok }>=300 \mathrm{~m}, 6=\text { ukuran diagonal blok }>=200 \mathrm{~m}, 8=\text { ukuran } \\
\text { diagonal blok }>=100 \mathrm{~m}, 10=\text { ukuran diagonal blok }<100 \mathrm{~m} \\
\text { - Prioritized Connectivity } / \text { ketersediaan jalan dan persimpangan khusus pejalan kaki } \\
\text { terhadap jalan dan persimpangan untuk kendaraan bermotor ( } 5 \text { points) }: 0=\text { tidak } \\
\text { tersedia, } 3=\text { tersedia }<=50 \text { persen, } 5=\text { tersedia }<=100 \text { persen }\end{array}$ \\
\hline Transit & $\begin{array}{l}\text { Fasilitas transit } \\
\text { dapat dicapai } \\
\text { berjalan kaki }\end{array}$ & $\begin{array}{l}\text { Walk Distance to Transit (TOD Requirement) : lokasi terminal wajib berada dalam } \\
\text { jangkauan berjalan kaki dari permukiman terdekat, bila tidak terpenuhi maka nilai } \\
\text { keseluruhan dianggap (0) nol }\end{array}$ \\
\hline Mix & $\begin{array}{l}\text { Penggunaan } \\
\text { lahan yang } \\
\text { beragam dan } \\
\text { saling } \\
\text { melengkapi }\end{array}$ & $\begin{array}{l}\text { - Complementary Uses/guna lahan disekitar terminal ( } 10 \text { points) }: 0=\text { guna lahan satu } \\
\text { jenis, } 5=\text { guna lahan dua jenis, } 10=\text { guna lahan lebih dari dua jenis } \\
\text { - Accessibility to Food/terminal berada dalam walk distance menuju pasar tradisional ( } 1 \\
\text { points) }: 0=\text { jauh dari pasar tradisional, } 1=\text { dekat dengan pasar tradisional } \\
\text { - Affordable Housing/tersedia perumahan subsidi }(4 \text { points }): 0=\text { tidak tersedia } \\
\text { perumahan subsidi, } 2=\text { tersedia perumahan subsidi }<=50 \text { persen dari keseluruhan } \\
\text { perumahan di sekitar terminal, } 4=100 \text { persen perumahan disekitar terminal adalah } \\
\text { perumahan subsidi }\end{array}$ \\
\hline Densify & $\begin{array}{l}\text { Kepadatan guna } \\
\text { lahan perumahan }\end{array}$ & $\begin{array}{l}\text { Density ( } 15 \text { point) : } 0=\text { kepadatan bangunan perumahan }>100 \text { unit } / \text { ha, } 7=\text { kepadatan } \\
\text { bangunan }>=50 \text { unit } / \text { ha, } 15=\text { kepadatan bangunan }<50 \text { unit } / \text { ha }\end{array}$ \\
\hline Compact & $\begin{array}{l}\text { Terminal berada } \\
\text { pada area } \\
\text { perkotaan }\end{array}$ & $\begin{array}{l}\text { Urban Site ( } 10 \text { points) : } 0=\text { keliling area terminal merupakan area belum terbangun, } 5 \\
\text { = sebagian area sekitar terminal belum terbangun, } 10=\text { terminal berada pada area } \\
\text { terbangun } \\
\text { - Transit Options ( } 5 \text { points) }: 0=\text { akses menuju dan dari terminal hanya dapat diakses } \\
\text { dengan kendaraan pribadi, } 5=\text { terdapat moda transportasi umum untuk menuju } \\
\text { terminal }\end{array}$ \\
\hline Shift & $\begin{array}{l}\text { Meminimalisir } \\
\text { lahan yang } \\
\text { digunakan untuk } \\
\text { kendaraan } \\
\text { bermotor selain } \\
\text { angkutan umum }\end{array}$ & $\begin{array}{l}\text { Off-Street Parking/ketersediaan parkir dalam terminal (10 points) : } 0=\text { lahan parkir } \\
>=50 \text { persen luar terminal, } 3=\text { lahan parkir }>=30 \text { persen luas terminal, } 6=\text { lahan parkir } \\
>=10 \text { persen luas terminal, lahan parkir }<10 \text { persen } \\
\text { - Driveway Density/jumlah jalur akses kendaraan pribadi }(2 \text { points) }: 0=>=3 \text { jalur, } 2=<3 \\
\text { jalur } \\
\text { - Roadway Area ( } 8 \text { points) }: 0=\text { area kendaraan bermotor }>=20 \text { persen dari penampang } \\
\text { jalan depan terminal, } 5=\text { area kendaraan bermotor }>=10 \text { persen, } 8=\text { area kendaraan } \\
\text { bermotor }<10 \text { persen }\end{array}$ \\
\hline
\end{tabular}


Tabel 2. Pembatasan Indikator

\begin{tabular}{lll}
\hline Variabel & \multicolumn{1}{c}{ Indikator } & \multicolumn{1}{c}{ Pertimbangan } \\
\hline Cycle & Cycle Access in & Belum terdapat \\
& Buildings (1 & peraturan daerah \\
& point) & secara formal yang \\
& & mengatur pembatasan \\
& & sepeda masuk dan \\
& & keluar area bangunan \\
\hline
\end{tabular}

Sumber: Hasil Analisa. 2017

Pengurangan poin indikator berdampak pada berkurangnya poin akhir penilaian, pengurangan 1 poin pada variabel Cycle akan ditambahkan pada variabel Mix, sehingga indikator Affordable Housing menjadi 5 poin.

\section{HASIL DAN PEMBAHASAN}

Penilaian dilakukan pada area dalam radius 250 meter dari Terminal Pal Enam Kota Banjarmasin. Penentuan radius didasarkan pada perkiraan maksimal jarak berjalan kaki yang nyaman dapat dilakukan dari dan menuju area terminal. Area terminal dan radius penilaian dapat dilihat pada Gambar 2.

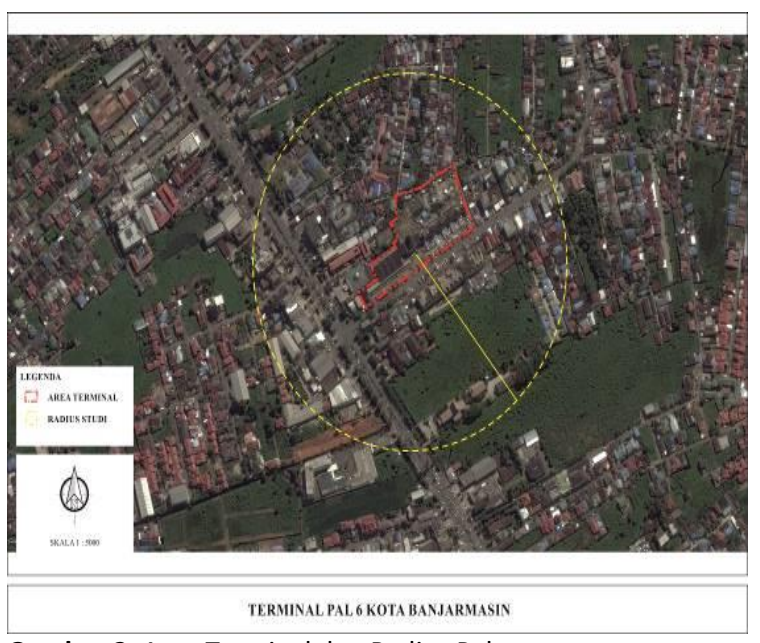

Gambar 2. Area Terminal dan Radius Pelayanan

Sumber: Hasil Analisa. 2017

Penilaian dilakukan menggunakan tabel penilaian yang memuat variabel, indikator, poin penilaian, catatan penilaian, data dokumentasi. Tabel penilaian dapat dilihat pada Tabel 3.

Total poin dari hasil penilaian Terminal Pal Enam Kota Banjarmasin adalah 59 poin. Hasil tersebut kemudian disesuaikan dengan range ranking TOD dengan klasifikasi dan spesifikasi dapat dilihat pada Tabel 4.
Tabel 4. Ranking Penilaian

\begin{tabular}{|c|c|c|}
\hline Klasifikasi & $\begin{array}{c}\text { Range Poin } \\
\text { Penilaian }\end{array}$ & Spesifikasi \\
\hline 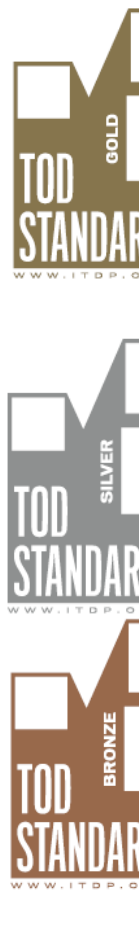 & $\begin{array}{l}\text { 55-69 Poin } \\
\text { (Nilai } \\
\text { Terminal Pal } \\
\text { Enam = 59 } \\
\text { Poin) }\end{array}$ & $\begin{array}{l}\text { Proyek, kawasan, } \\
\text { area dapat } \\
\text { dijadikan sebagai } \\
\text { Global Leaders } \\
\text { pada semua aspek } \\
\text { terkait desain } \\
\text { perkotaan dan } \\
\text { transportasi } \\
\text { terintegrasi } \\
\text { Proyek, kawasan, } \\
\text { area memenuhi } \\
\text { sebagian besar } \\
\text { indikator dan } \\
\text { dapat menjadi } \\
\text { percontohan } \\
\text { sistem integrasi } \\
\text { berkualitas tinggi } \\
\text { Proyek, kawasan, } \\
\text { area termasuk } \\
\text { kedalam kriteria } \\
\text { penilaian } \\
\text { memuaskan } \\
\text { dalam memenuhi } \\
\text { pembangunan } \\
\text { perkotaan } \\
\text { berbasis transit }\end{array}$ \\
\hline
\end{tabular}

Sumber: Hasil Analisa. 2017

\section{KESIMPULAN}

Terminal Pal Enam Kota Banjarmasin dengan fungsinya sebagai fasilitas transit bagi kegiatan transportasi dalam kota maupun antar kota saat ini telah berada pada lokasi yang tepat dan dapat menunjang pengembangan Kota Banjarmasin bila pengembangan dengan tema TOD akan diterapkan. Lokasi Terminal Pal Enam Kota Banjarmasin bukan hanya sebagai Kawasan Strategis Ekonomi yang mewadahi transit dan keterpaduan antar moda namun juga mampu memenuhi ekspektasi sebagai salah satu area pionir dalam desain perkotaan TOD.

Kedepannya, tema pengembangan kota berbasis TOD, mengacu pada Permen ATR BPN RI Nomor 16 Tahun 2017 tentang Pedoman Pengembangan Kawasan Berorientasi Transit dapat dilaksanakan di Kota Banjarmasin khususnya Terminal Pal Enam dan area disekitarnya sebagai kawasan berorientasi transit. 
Tabel 3. Penilaian

\begin{tabular}{|c|c|c|c|c|c|}
\hline Variabel & Indikator & Range & Poin & Catatan Penilaian & Dokumentasi \\
\hline \multirow[t]{5}{*}{ Walk } & Walkways & $0-3$ & 2 & $\begin{array}{l}\text { Pada } 3 \text { segmen jalan di area sekitar terminal, } 2 \\
\text { segmen telah tersedia pedestrian way }\end{array}$ & \\
\hline & Crosswalk & $0-3$ & 1 & $\begin{array}{l}\text { Pada } 3 \text { segmen jalan di area sekitar terminal, } 1 \\
\text { segmen telah tersedia area penyeberangan } \\
\text { jalan }\end{array}$ & \\
\hline & $\begin{array}{l}\text { Visually Active } \\
\text { Frontage }\end{array}$ & $0-6$ & 4 & $\begin{array}{l}\text { Pada } 3 \text { segmen jalan di area sekitar terminal, } 2 \\
\text { segmen memiliki fasad bangunan yang dapat } \\
\text { diakses secara visual oleh pengguna jalan }\end{array}$ & \\
\hline & $\begin{array}{l}\text { Physically } \\
\text { Permeable } \\
\text { Frontage }\end{array}$ & $0-2$ & 2 & $\begin{array}{l}\text { Pada } 3 \text { segmen jalan di area sekitar terminal, } \\
\text { Secara keseluruhan memiliki fasad bangunan } \\
\text { yang dapat diakses oleh pengguna jalan }\end{array}$ & \\
\hline & $\begin{array}{l}\text { Shade \& } \\
\text { Shelter }\end{array}$ & $0-1$ & 1 & $\begin{array}{l}\text { Pada } 3 \text { segmen jalan di area sekitar terminal, } \\
\text { Secara keseluruhan memiliki fasad bangunan } \\
\text { yang dapat diakses oleh pengguna jalan }\end{array}$ & \\
\hline \multirow[t]{3}{*}{ Cycle } & Cycle Network & $0-2$ & 0 & $\begin{array}{l}\text { Tidak tersedia jalur sepeda, Pada } 3 \text { segmen } \\
\text { jalan di area sekitar terminal }\end{array}$ & \\
\hline & $\begin{array}{l}\text { Cycle Parking } \\
\text { at Transit } \\
\text { Stations }\end{array}$ & $0-1$ & 0 & $\begin{array}{l}\text { Tidak tersedia parkir sepeda, Pada area } \\
\text { terminal }\end{array}$ & \\
\hline & $\begin{array}{l}\text { Cycle Parking } \\
\text { at Buildings }\end{array}$ & $0-1$ & 0 & $\begin{array}{l}\text { Tidak tersedia parkir sepeda, Pada bangunan- } \\
\text { bangunan di } 3 \text { segmen jalan sekitar terminal }\end{array}$ & \\
\hline \multirow[t]{2}{*}{ Connect } & Small Block & $0-10$ & 8 & $\begin{array}{l}\text { Beberapa blok Pada } 3 \text { segmen jalan di area } \\
\text { sekitar terminal berukuran } 150 \mathrm{~m} \text {, blok yang } \\
\text { lain berukuran kurang dari itu }\end{array}$ & \\
\hline & $\begin{array}{l}\text { Prioritized } \\
\text { Connectivity }\end{array}$ & $0-5$ & 0 & $\begin{array}{l}\text { Semua jalan pada area sekitar terminal } \\
\text { digunakan bersamaan oleh kendaraan } \\
\text { bermotor, kendaraan tidak bermotor, dan } \\
\text { pejalan kaki }\end{array}$ & \\
\hline
\end{tabular}

Transit

Walk Distance Lokasi terminal berada dekat dengan permukiman $(<500 m)$ to Transit 


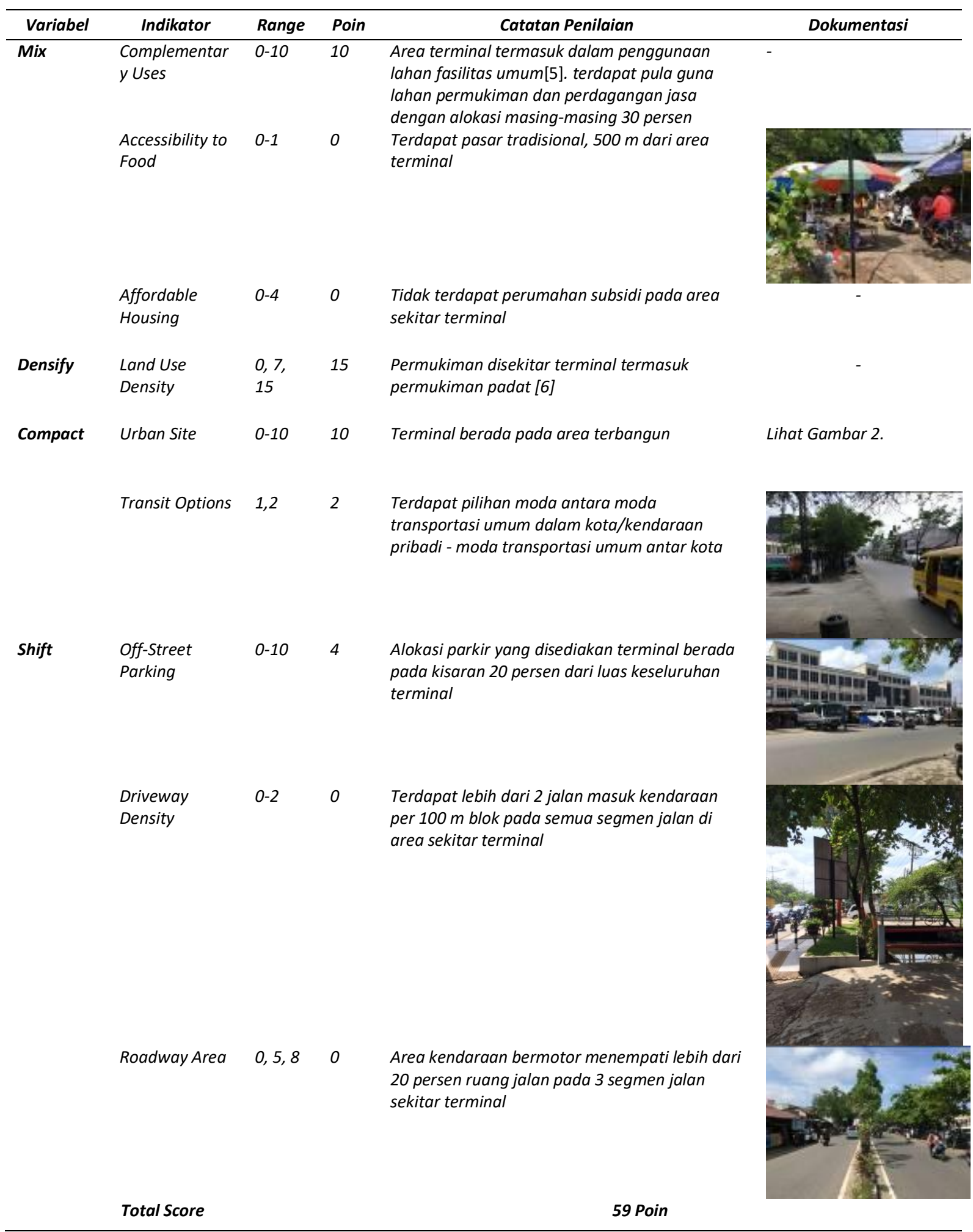




\section{UCAPAN TERIMA KASIH}

Terima kasih peneliti ucapkan kepada UPTD Terminal Pal Enam Dinas Perhubungan Provinsi kalsel, atas kerjasama dan dukungan dalam kelancaran kegiatan survey dan analisa serta masukan data untuk kemajuan penelitian

\section{DAFTAR PUSTAKA}

[1] ITDP. (2014). TOD Standard v2.1. New York: Despacio

[2] Hayati, S Hasibuan., Tresna, P Soemardi., Raldi Koestoer., Setyo Moersidik. (2014). The Role of Transit Oriented Development in constructing urban environment sustainability, the case of Jabodetabek, Indonesia. Procedia Environmental Sciences 20 (2014) $622-631$.

[3] Taki, Herika Muhammad., Maatouk, Mohamed Mahmoud H., Qurnfulah, Emad Mohammad., Aljoufie, Mohammed Omayer. (2017). Planning TOD with land use and transport integration: a review. Journal of Geoscience, Engineering, Environment, and Technology Vol 02 No 01 (2017) 84-94

[4] Toding, Kosmas., Jinca, M. Yamin., Wunas, Shirly. (2012). Sistem Transit Oriented Development (TOD) Perkeretaapian Dalam Rencana Jaringan Kereta Api Komuter MAMMINASATA. Makassar: Pascasarjana Universitas Hasanuddin.

[5] Widayanti, Rina., Susanto, Remigius Hari. (2013). Kajian Sistem Transit Oriented Development di Daerah Mixed Use dan Kepadatan Tinggi (Studi Kasus: Kota Depok). Jakarta: Universitas Gunadharma

[6] Aditya, V Sohoni., Mariam Thomas., K V Krishna Rao. (2017). Application of the concept of transit oriented development to a suburban neighbourhood. Transportation Research Procedia 25 (2017) 3220-3232

[7] Netti, Nelma. (2016). Evaluasi Penataan Kawasan Terminal Simpang Aur Kuning Kota Bukittinggi. JOM FISIP Vol. 3 No.2 Oktober 2016

[8] Pemerintah Kota Banjarmasin. (2012). City Visioning Profile: Banjarmasin, Kalimantan. Banjarmasin: UN-HABITAT

[9] Kementerian ATR BPN. (2017). Peraturan Menteri ATR BPN RI Nomor 16 Tahun 2017 tentang Pedoman Pengembangan Kawasan Berorientasi Transit. Jakarta: Kementerian Hukum dan HAM Republik Indonesia

[10] Pemerintah Kota Banjarmasin. (2013). Rencana Tata Ruang Wilayah Kota Banjarmasin Tahun 2013-2032.
Banjarmasin: Sekretaris Daerah Kota Banjarmasin

[11] Arief, Andi B. et al. (2015). Model Pengembangan Tata Ruang Transit Oriented Development (TOD) Kawasan Pelabuhan Kayu Bangkoa Makassar. Temu IImiah IPLBI 2015

[12] Ridhoni, Miftahul. (2017). Perumusan Indikator Aggregat Tingkat Keberlanjutan Kampung Dengan Pendekatan Fuzzy Logic (Studi Kasus: Kampung Tenement Kota Malang). Malang: FT-UB 